\title{
The Application of the Hassan Loan in Algeria: Social Experience and Solutions
}

\section{Ahmed Ameur Ameur Djamila Ahssen ${ }^{2}$}

${ }^{1,2}$ Faculty of Economic Sciences, Business and Management, University of Abdelhamid Ben Badis Kharrouba, Algeria.

Email:ameur_ameur@yahoo.com

¿Email:ahssendjamila@,outlook.fr

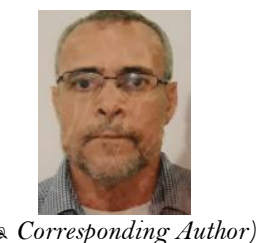

( Corresponding Author)

\section{Abstract}

In this paper we try to address the theory of the Hassan loan and the extent to which this type of loan, as an Islamic solution, can achieve successfully its social and economic goals in Algeria. We try also to address the experience of Algeria in the adoption of the Hassan loan and in investing Zakat ${ }^{1}$, organizing the collection of Zakat Funds, establishing a fund for charitable operations,-and exploiting zakat in the process of good lending. We will discuss the extent to which this type of loan, as an Islamic solution, can achieve successfully its social and economic goals in Algeria. On the other hand, we will tackle how this experience can be a catalyst for the foundation of investment associations, the establishment of Islamic banks and the preparation for the existence of Islamic banking in Algeria. Finally, we concluded that the experience of the Zakat Fund encouraged Muzakin and investors to deal with Islamic banks and expanded the applications of good loans at Islamic banks. On the other hand, we concluded that the successful operation of Hassan loan projects requires good management and strict monitoring and control.

Keywords: Hassan loan, Zakat, Islamic banking, Algeria, Social responsibility, Economic development, Islamic solution. JEL Classification: N2; L2; L1 1; E44; D1.

Citation | Ahmed Ameur Ameur; Djamila Ahssen (2019). The Application of the Hassan Loan in Algeria: Social Experience and Solutions. Economy, 6(2): 56-64.

History:

Received: 7 June 2019

Revised: 16 July 2019

Accepted: 20 August 2019

Published: 30 September 2019

Licensed: This work is licensed under a Creative Commons

Attribution 3.0 License (cc))

Publisher: Asian Online Journal Publishing Group
Acknowledgement: Both authors contributed to the conception and design of the study.

Funding: This study received no specific financial support.

Competing Interests: The authors declare that they have no conflict of interests.

Transparency: The authors confirm that the manuscript is an honest, accurate, and transparent account of the study was reported; that no vital features of the study have been omitted; and that any discrepancies from the study as planned have been explained.

Ethical: This study follows all ethical practices during writing.

\section{Contents}

1. Introduction

2. The Problem of Unemployment and Poverty in Algeria

.

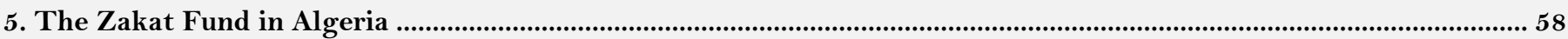

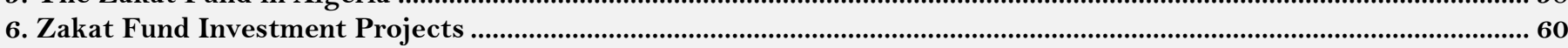

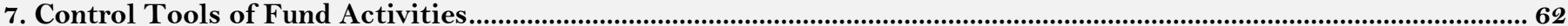

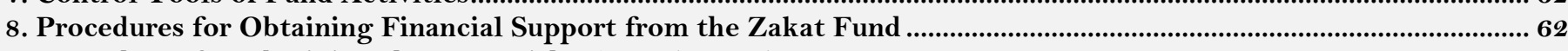

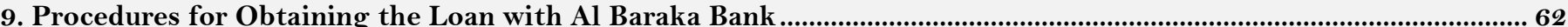

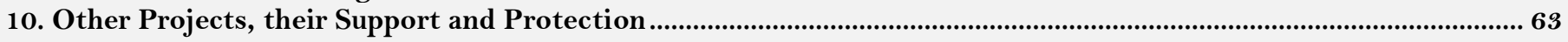

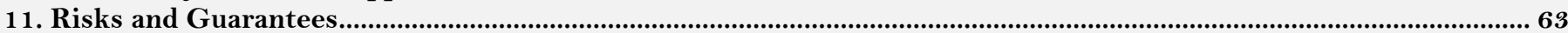

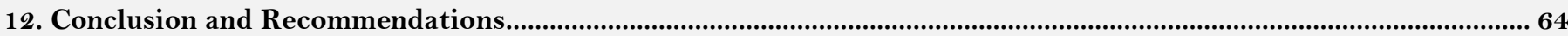

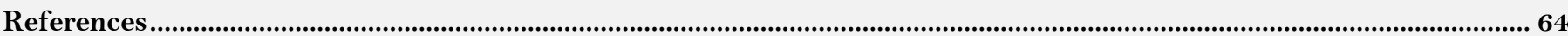




\section{Contribution of this paper to the literature}

This study contributes to existing literature by addressing the theory of the Hassan loan and the extent to which this type of loan, as an Islamic solution, can achieve successfully its social and economic goals in Algeria.

\section{Introduction}

Social solidarity and brotherly cooperation are considered to be one of the basic features that distinguish Muslim societies from others. The Muslim's faith in God calls upon him to help his Muslim brother with a benefit that does not seek reward or thanks. Rather, his goal is higher than that; it is about seeking the pleasure of Allah.

Since this era is witnessing a growing number of the needy and a decreasing number of benefactors and in the absence of rights and unprecedented excessive consumption of goods, it has become a necessity to launch a project that benefits the society, especially those with limited income. Hence, the idea of the Hassan loan in Islamic jurisprudence has come into existence contrary to capitalism which is founded on the basis of interest (usury, in Arabic riba). The goodly loan is "giving money to someone for the sake of getting closer to the Almighty God, in a way that the recipient benefits from the money then he returns the same amount".

Lending and borrowing is an old practice known to man. It exists and is available in the various banks in Algeria but operates according to the traditional financial system that charges interest. As the Algerian society is a Muslim one, it believes in the obligation of Zakat. The Algeria Ministry of Religious Affairs and Awqaf has established the Zakat Fund to collect and distribute Zakat and donations in a systematic manner to those in need and to alleviate poverty among communities.

To ensure that the project would play an active role and achieve its objectives, the task of administrative supervision of funds must be entrusted to an institution characterized by trust and excellence and works in the financial field, i.e. to a bank with a stress on halal transactions.

In this study, we will try to address the Algerian experience in investing Zakat ${ }^{2}$, organizing the collection of Zakat Funds, establishing a fund for charitable operations,-and exploiting zakat in the process of good lending. We will discuss the extent to which this type of loan, as an Islamic solution, can achieve successfully its social and economic goals in Algeria. On the other hand, we will tackle how this experience can be a catalyst for the foundation of investment associations, the establishment of Islamic banks and the preparation for the existence of Islamic banking in Algeria.

\section{The Problem of Unemployment and Poverty in Algeria}

In the recent period, there has been a rapid increase in the number of active people due to the fact that-Algeria has a large youth power. The labour force is registering a growing number of job seekers among the active class every day. However, what attracts more attention is that the majority of applicants to labour offices are young between 15 and 25 years. Many of them are trying to enter the working life for the first time, especially as they lack experience and qualification which makes it difficult for them to get a job.

Unemployment is a social phenomenon whose major result is poverty. Especially as we live in a time when money is everything, and the purely materialistic orientation dominates people's minds and crystallizes them materially as morale, ideals, values and ethics no longer have any effect. Poverty and destitution are equivalents to miserable life and have devastating effects on families and even communities; and coping with them is very difficult, especially if a person is accustomed to a decent life and a respectable social status.

The development of any programs and future plans to address the problem of employment is useless if there is no exact scientific crystallization of both employment and unemployment concepts and their extent. The importance of studying this issue in terms of its relevance and impact on the social construction of society that lies in social and economic aspects first and then security and health ones.

\section{The Islamic Solution}

Lending and borrowing is a practice that exists and is practiced by various banks in Algeria but operates according to the traditional interest based financial system. As the Algerian community is a Muslim society, it believes in Zakat. The Ministry of Religious Affairs and Awqaf in Algeria has established the Zakat Fund to collect and distribute Zakat and donations in a systematic manner to those in need and to alleviate poverty among communities.

God says, "Cooperate on righteousness and piety and do not cooperate in sin and transgression."[Al-Maida verse 2$]^{3}$. This is because of the great social and humanitarian benefits that cooperation would bring such as social solidarity, interdependence, brotherhood and love. The material cooperation is the provision of Zakat and charity through paying Zakat and applying Sharia. Cooperation is a key to any problem that can happen to Muslims and enables them to meet the needs of their poor and needy people, and to eliminate poverty among their societies.

In Algeria, the Ministry of Religious Affairs and Awqaf established the Zakat Fund and fundraisers worked on the three levels: the basic, the provincial and the national. One of these solutions is the application of the Zakat and the ability to raise funds and distribute them systematically to those in need, to meet the needs of the poor and needy, and to eliminate poverty among societies. Including that governments, through the institutions concerned, invest the funds effectively and efficiently in housing delivery and selling them to workers-who can pay the price in instalments rather than lending them with interest they call administrative costs. The sale by instalments or payment by instalments is permissible in Sharia, even at prices higher than the original value. This system also applies to vehicles that governments buy and sell to workers.

Other solutions, for example, the establishment of Awqaf institutions,-through which benefactors donates types of funds as ongoing charity, that would allow them to accumulate rewards while they are alive and even after they

${ }^{2}$ See the concept and meaning of Zakat in chapter 6 page 5 . 
pass away. We must also know that these institutions cannot be set up in a moment and that their fruits cannot be realized overnight.

Islamic banks are considered part of these Islamic solutions. The idea of establishing them has emerged in the Islamic world mainly it focuses on accumulating savings and investing them in accordance with the Islamic Sharia rules; in order to achieve the best returns for owners of these banks as well as contributors and investors. It has come to face the usurious transactions that are the core of traditional Western banks. These banks were originally based on the logic of good interest-free loans and have evolved into their current form.

\section{Good Loan}

\subsection{Definition of Good Loan}

The treatment of lending and borrowing is an old issue that has been familiar to man since his first age. And since man is a social being who cannot live alone; people were lending from each other, as they were selling, buying and exchanging goods and benefits. Muslims knew the Good loan (in Arabic: Al-Qard Al-Hassan) by the coming of Islam; it was every material thing, in cash or other forms, the Muslim returns to his Muslim brother without interest, seeking the reward of the Hereafter. The meaning of the loan in this sense is mentioned in the Holy Quran six times, including what is stated in Surat Al-Baqarah,: "Fight for the sake of Allah, and know that Allah is Hearer of Knowledge." Who will lend a good loan to Allah? You shall return\} [al-Baqarah: 244-245] $]^{4}$.

A Loan ${ }^{5}$, or an advance, is that the owner parts from his money for a period of time lending it to his brother the needy, where a refund is required after a certain maturity without requiring an increase ${ }^{6}$. This concept has become known as the Islamic Bank's offering of a fixed amount of money to an individual or to a client, even if it is a company or a government. The lender guarantees the repayment of the good loan without any burdens or claiming for interests or return on the investment of the money or any increase of any kind, but the bank recovers the face value of the loan only (Publications of the Ministry, 2009)".

"The concept of Al-Hassan loan in Algeria has recently been related to the investment of money derived from the Zakat of Muslims, Zakat al-Fitr and Zakat money, in the form of subsidies in support of needy borrowers. The lender here is the Ministry of Religious Affairs and Awqaf in Algeria, where it deals with the "Al Baraka" Islamic Bank "(Mohammed and Mohammed, 2006) as the Zakat Funds agent in the financial (Ministry of Religious Affairs and Endowments, 2004) management.

The initiative of establishing the Zakat Fund and initiating the work of the loan can also be credited to:

1. Building the desired Islamic economic system.

2. To complete the channels of legitimate financing.

3. To encourage the establishment of Islamic banks in Algeria and to correct the image of Islamic banks in general and to close the doors on the prejudiced views.

Al Baraka Bank or other Islamic banks that will be established in the future will also benefit from the adoption of Al Hassan Loan Project:

1. Increase the customer base.

2. Stabilize the roots of the bank in the community in which it lives and people stand with it and support it in a crisis period, especially in the circumstances of globalization where the competition intensity requires maintaining customers.

3. Achieving a legitimate economic precedent.

4. Increase the investment portfolios it manages and gains from them financial profits as well as moral profits, through the management of Waqf funding portfolios.

\subsection{Documenting the Good Loan}

In order to avoid the risk of non-compliance with the borrowed money, Islamic law has made the lender's money some documents in order to reassure the lender about having his money back. The documentation of the debt can be in a written form, as in the verse: ( $\mathrm{O}$ ye who believe if you ... the martyrs if they call and do not be bored to write him small or large to it) [Baqarah: 282 $]^{7}$.

It is also possible to document the debt by witness as in the verse:(Al-Baqarah: 283). It is proven in the Sunnah that it is not related to the condition of travelling, because it is narrated by Aisha (may Allaah be pleased with her)that the Prophet (peace and blessings of Allah be upon him) purchased food grains from a Jew on credit and mortgaged his iron armour to him. And finally to document the debt by guarantee-in which someone should pay the debt of another he does not repay it.

\section{The Zakat Fund in Algeria}

\subsection{The Definition and Origin of the Zakat Fund in Algeria}

A rich Muslim looks at his money and his wealth as a trust that Allah has entrusted to him. He should perform his right and use it in the satisfaction of Allah. God urges Muslims to spend their money to meet the needs of the poor and the needy.

Zakat is one of the pillars of Islam ("Those who believe and do righteous deeds and set up prayer and pay zakaah for them are rewarded by their Lord and there is no fear for them nor do they grieve" (Baqarah 2-Aya 277) is the first system known to mankind to achieve care for the needy and social justice among the members of the society through their distribution of part of the wealth of the rich to the poor and the needy. It is a money obligation imposed on rich Muslims and is a percentage of the Muslim's money to the house of Muslim money. The

The loan and advances are two words in tandem; just as the loan is the act of lending money to someone in condition that the borrower refunds the same sum of the money to the lender, the advance is the same. But the debtis general; it is called loan, ba'i al-Salam, and ba'i al-Ajel. It is ((every transaction in which one of the compensators in cash and the other is Nasi'ah)). In the Arabic culture, the Nasi'ah is what is present while the debt is what is absent. According to the Islamic law, the loan is divided into two parts: a good loan and riba loan. 
zakat has two types: zakat al-fitr and zakat of money. Zakat al-fitr is paid in the month of Ramadan and is obligatory on everyone who has his food for the day and his family's; and its value is fixed each year, .The zakat of money is imposed on the one who owns the Nisaab ${ }^{9}$ and one year has passed since this latter has been reached. Zakat includes gold and silver etc. And the zakat of crops is paid when the crops are harvested without waiting for the one year to pass. Zakat is the amount of $2.5 \%$ of annual savings if a certain value known as Nisaab is exceeded.

After a long discussion in the laboratories of researchers as well as at the level of universities and among scholars and those interested in the Islamic issue-the Ministry of Religious Affairs and Awqaf in Algeria,-has succumbed and adopted the project of establishing the Zakat Fund which saw the light in $2003^{10}$.

The Zakat Fund is a religious, social and charitable institution that works to raise Zakat funds from the benefactors supervised by bodies operating under the authority of the Ministry of Religious Affairs and Awqaf. The Zakat Fund is organized and distributed to needy Muslims in Algeria. The Ministry of Religious Affairs and Awqaf in Algeria also supervises it by guaranteeing the legal coverage according to the law governing the mosque institution.

\subsection{Work and Tasks of the Zakat Investment Fund}

Initially, the funds of the Zakat Fund were distributed only to the needy and needy families, whose members are unable to work such as divorced women and widows with children, the elderly people and the disabled without income or an official grant. The subsidy is provided annually, half a year or every three months. As the number of unemployed and unemployed university graduates grew and the income of the Fund grew, the use of the Zakat Fund expanded to include the investment process.

The Zakat Investment Fund is a fund that is deducted from the Zakat Fund and is allocated to the lending process for certain groups of society in Algeria. It is known in other Islamic countries as the Al-Qard Al-Hassan Fund. The creation of this fund has contributed to the fight against poverty and the absorption of unemployment, especially among the increasing number of young people, educated and uneducated. The new fund aims to exploit part of the Zakat funds provided to young unemployed graduates from universities and vocational training centres on the one hand and to artisans and productive families in the labour market and other groups capable of working, such as women and young women who make houses.

The establishment of the fund is in line with the principle of "We do not give him to remain poor, but to become a muzaki ${ }^{11}$ (person who pays the Zakat funds)". Thus, the investment process of Zakat funds is a noble and legitimate goal that the Fund seeks to achieve. The aim is to employ the unemployed, support the young people integrating them into the professional life to realise their dreams, reduce the number of poor and turn them from recipients of Zakat to muzakis. The most important feature of this fund in Algeria is its applications, especially those related to supporting projects for employing youth and the other different categories of the unemployed. They complement and even match the work of youth and unemployment support agencies and others in the field funded by banks but with interest rates.

\subsection{Management of Zakat Fund}

The Zakat Fund has been entrusted to specialized competencies in the administrative and financial fields. The Zakat Fund is composed of three organizational management committees: the Basic Committee, the Provincial Committee and the National Committee.

As for the basic committee ${ }^{12}$, it will be at the level of each constituency and consists of mosque committees (the number of mosques across the entire territory of the same constituency). The mosque is the main cell in the process of sensitizing worshipers and solidarity. The committee's work is supervised by a deliberative committee composed of the chairman of the committee, the chairpersons of the mosque committees, the representatives of neighbourhood committees, representatives of the dignitaries, and representatives of the benefactors. Its mission is to identify Zakat beneficiaries at the level of each constituency.

The Provincial Committee is at the level of each province and is entrusted with the final study of Zakat files at the provincial level; and this stage is placed after the initial decision at the level of the Basic Committee. Its deliberative committee consists of the Chairman of the Provincial Commission, two highly ranked imams, the head of the province Scientific Council, two jurists, an accountant, an economist, a social assistant, the heads of the grassroots bodies. Finally, the National Committee which is the Supreme Council of the Zakat Fund, which consists of the President of the Council, the heads of the Zakat Fund's State Committees. It consists of the Shariah Board members, the Supreme Islamic Council representative, two representatives of the ministries involved in the Fund, the senior benefactors. Its main tasks are summarized as the organizing body for everything related to the Zakat Fund in Algeria.

\subsection{Collection of Zakat Funds and its Disbursement in Algeria}

Zakat funds can be collected according to different regulations. In fact, the person who pays zakat or the donor can obtain them at the post offices using the postal hawala system across the entire national territory. The full name should be written completely or writing expressions like "Zakat Funder, charitable"; in addition to that, is added the amount paid written both in numbers and letters and stating the zakat fund account number. He can likewise use the cheque to write the amount paid in both numbers and letters and then pay through the post office, where it referred the Zakat Fund Account Number corresponding to each state. Furthermore, there is a third method used to collect zakat funds, which is through boxes placed in mosques, and this is to facilitate the payment process forthe citizen who unable pay through post offices. He/ or she then receives from the imam of the mosque

${ }^{9}$ The Nisaab (quorum) is the amount of money specified by sharia law, which then becomes obligatory for the believer who has to pay zakaat for a sum greater than this sum, which he has had for a year.

he has had for a year. 10 The Zakat Fund was established on the basis of the provisions of Executive Decree No. 91-81 dated 7 th of Ramadan $1411 \mathrm{H}$ corresponding to $23 \mathrm{March} 1991$ concerning the
building, organization, administration and assignment of the mosque, in particular Articles 15 and 22 , as well as the provisions of Executive Decree No. $91-82$ of 7 Ramadan $1411 \mathrm{H}$ building, organization, administration and assignment of the mosque, in particular Articles 15 and 22 , as well as the
corresponding to March 23,1991 , which includes the establishment of the mosque institution, especially Article 3. 
(the leader of the prayer)a voucher indicating that he paid his zakat through these funding boxes, and he can assist the body responsible of the censorship by sending a copy of it to the local, regional, or national committee.

In addition, expatriates abroad can pay their Zakat on the basis of transferring the zakat to the National Fund of Zakat Fund by means of international transfer or any other, where it should include name, the national ID number of Zakat fund (10-4780) and Zakat amount in both letters and numbers.

The method of its distribution is that the mosque committees enumerate the people who are both in the poor and the needy category (the enumeration process is done on the basis of families and not individuals) in the neighbourhoods surrounding the mosque based on a specific form supported by documents showing the social status of the family. The lists shall be then sent to the Local Committee at the level of the Daïra ${ }^{13}$ to be ordered and approved. Finally, the files shall be sent to the State Committee of the Zakat Fund for the disbursement of the funds by means of postal remittances or checks.

In regards to Zakat funds collected; they are disbursed according to the final deliberations of the state committee. A part of them goes to poor families; and this is according to priority by giving them a sum of money annually, every six or three months.

Another part is directed towards investing in favour of the poor where a portion of zakat funds is allocated for investment, such as the interest-free loan (Al Hassan Loan) method or the method of purchasing working tools/ materials which young people will benefit from in small and micro enterprises, similarly is the case involving conventional banks. There is a possibility of setting two different cases in relation to the disbursement of Zakat funds collected according to certain ratios:

Case 1: If the state outcome does not exceed five million Algerian Dinar of Zakat funds, what equals $87.5 \%$ is disbursed to the poor families and those in need; whereas, the remaining part i.e. (12.5\%) is allocated to cover the activities of the Zakat Funds collection.

Case 2: If the state revenues exceed 5 million Algerian Dinar, $50 \%$ of the collected zakat funds will be distributed to the poor families and those in need (the amounts are fixed).the $37.5 \%$ will be distributed in the form of interest-free loans to individuals who are able to work. The remaining amount (12.5\%) will be allocated to cover the activities of the Fund, which are distributed as follows:

- $4.5 \%$ to cover the costs of the activities of the State Committee.

- $6 \%$ to cover the costs of the activities of the Local Committees.

- $2 \%$ is waged to the national account to cover the activities of the Fund at the national level.

\section{Zakat Fund Investment Projects}

The Zakat Fund has been established in Algeria to serve as one of the many other tributaries fighting unemployment and supporting youth employment projects. What is most importantly distinguishing it from others of its kind in Algeria is its applications, especially those related to supporting youth employment projects and the unemployed under all their different categories. These applications complement and even match the work of youth and unemployment support agencies and others that have been operating in the field for years and are funded by banks but with interest.

This support and funding include almost all state-supported projects supported by the National Agency for Employment and Youth Support (ANSEJ) youth and the National Unemployment Insurance Fund (CNAC) to support the older category of unemployed young people to acquire equipment and tools or to establish small enterprises and microenterprises. We remark the following projects:

1. Youth support and employment projects.

2. Projects of the National Unemployment Insurance Fund.

3. Micro-projects.

4. Projects secured by the Loan Guarantee Fund (associated with the Ministry of Small and Medium Enterprises).

5. Assisting institutions that are able to recover.

6. Establishment of joint ventures between the interest-free loan fund Al-Qard and the bank (Al Baraka Bank, which was adopted as an agent).

Here after are the statistics on the zakat development Table 1.

Table-1.The development of the national income of zakat in Algeria between 2003 and 2014.

\begin{tabular}{c|c|c|c|c|c}
\hline year & Income of zakat & Log(zakat) & year & Income of zakat & Log(zakat) \\
\hline 2003 & 56122571,95 & 7,75 & 2009 & 936683237,40 & 8,97 \\
\hline 2004 & 239853996,00 & 8,38 & 2010 & 899192808,60 & 8,95 \\
\hline 2005 & 508656551,80 & 8,71 & 2011 & 1179063794,00 & 9,07 \\
\hline 2006 & 686440187,50 & 8,84 & 2012 & 1306642512,00 & 9,12 \\
\hline 2007 & 732514125,30 & 8,86 & 2013 & 1294152265,00 & 9,11 \\
\hline 2008 & 654451244,60 & 8,82 & 2014 & 1318759818,00 & 9,12 \\
\hline
\end{tabular}

https://www.marw.dz/index.php/2015-03-24-13-19-40/39-2010-01-06-09-43-18.html

Below the graph corresponding to the data of the zakat (in log) Figure 1. 


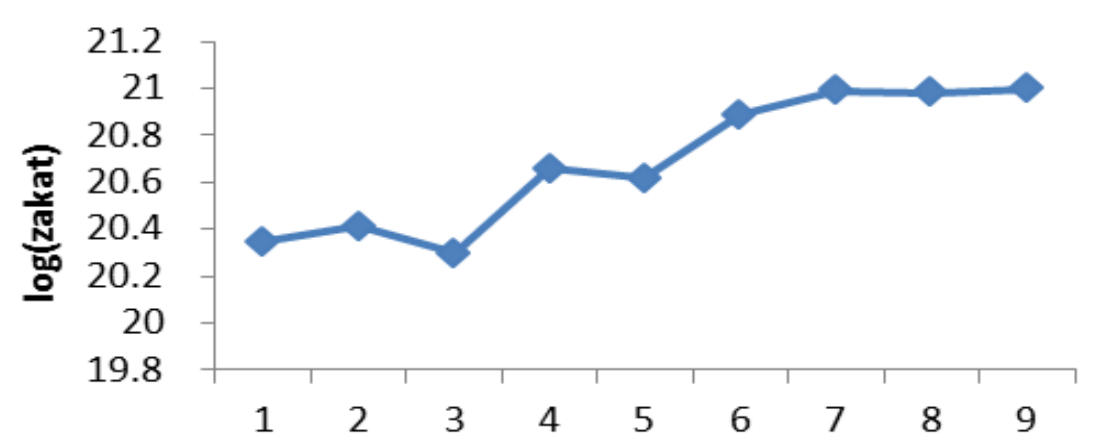

Figure-1. Evolution of the national income of zakat (in log) between 2003 and 2014. Source: From the researcher's creation according to the Table 1.

The increase in the national income of zakat has led to the growing number of poor families and those in need in which the fund is entitled zakat Al-Fitr (MRAE, 2004) with the financing of an important number of open projects and the establishment of small and micro enterprises. The following statistics are presented in Table 2.

Table-2. Evolution of the national outcome of zakat and other parameter between 2003 and 2008

\begin{tabular}{l|c|c|c|c|c|c}
\hline Statement / Year & $\mathbf{2 0 0 3}$ & $\mathbf{2 0 0 4}$ & $\mathbf{2 0 0 5}$ & $\mathbf{2 0 0 6}$ & $\mathbf{2 0 0 7}$ & $\mathbf{2 0 0 8}$ \\
\hline Amount of fund zakat (Million DZA) & 57,789 & 200,5 & 367,187 & 483,584 & 566,814 & \\
\hline The proceeds of Zakat al - Fitr & 50 & 114,986 & 257,155 & 320,611 & 232,316 & \\
\hline Number of projects of interest-free loan - & - & 242 & 600 & 1214 & 1350 & \\
\hline Number of families benefiting from zakat & 21000 & 35500 & 53500 & 62500 & 70000 & \\
\hline Number of families benefiting from zakat al -Fitr & 30000 & 46000 & 102862 & 128244 & 116158 & \\
\hline Number of open projects & 256 & 466 & 857 & 1147 & 800 & 1200 \\
\hline
\end{tabular}

The corresponding descriptive diagrams are presented as follows:

1. Evolution of the national outcome of zakat (Zakat money and value of Zakat al - Fitr) between 2003 and 2008 Figure 2.

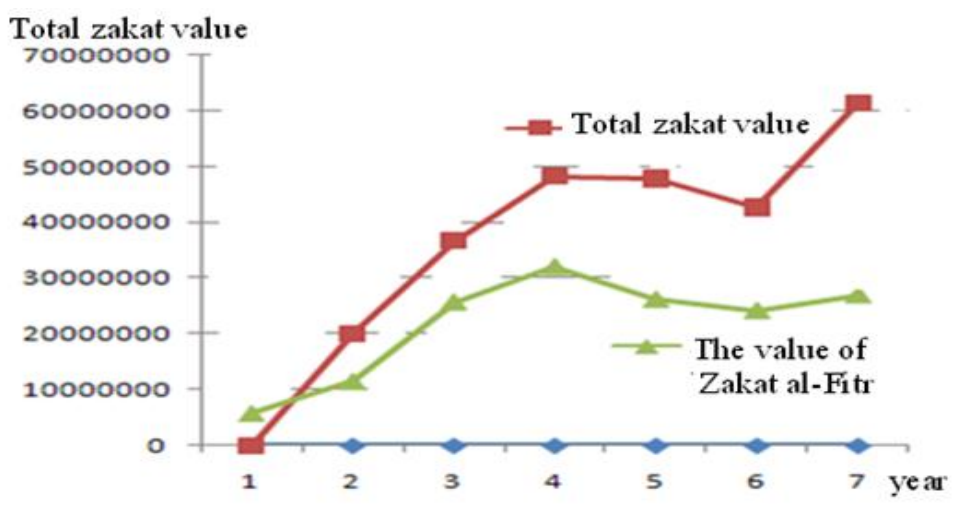

Figure-2. Evolution of the national outcome of Zakat and Zakat al fitr between 2003 and 2008

Source: From the researcher's creation according to the data of Table 2.

2. Development of the number of families benefiting from the zakat Fund (Zakat of zakat and zakat al Fitr) Figure 3.

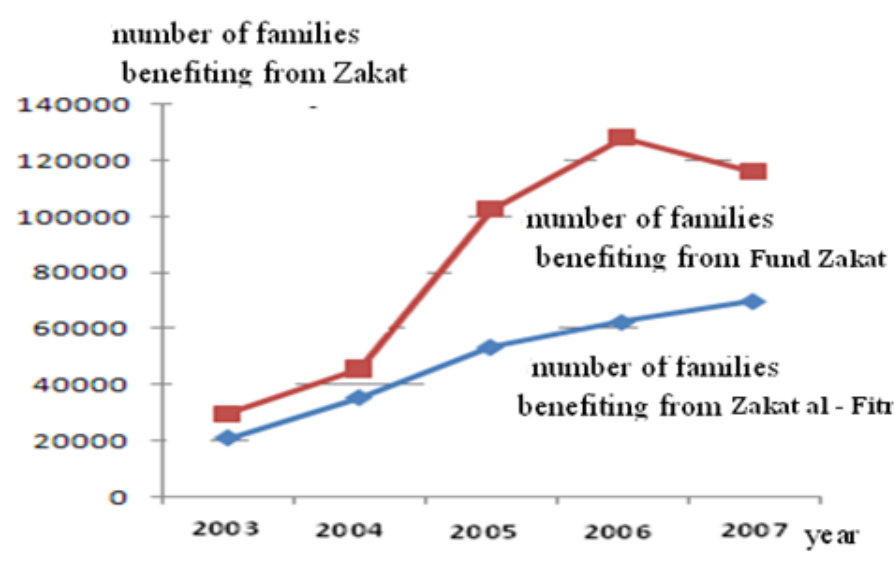

Figure-3. Evolution of the number of families benefiting from Zakat between 2003 and 2008 .

Source: From the researcher's creation according to the Table 2 .

3. Development of the number of open projects funded by the Investment Fund in the Zakat according to the Table 1, Figure 4. 


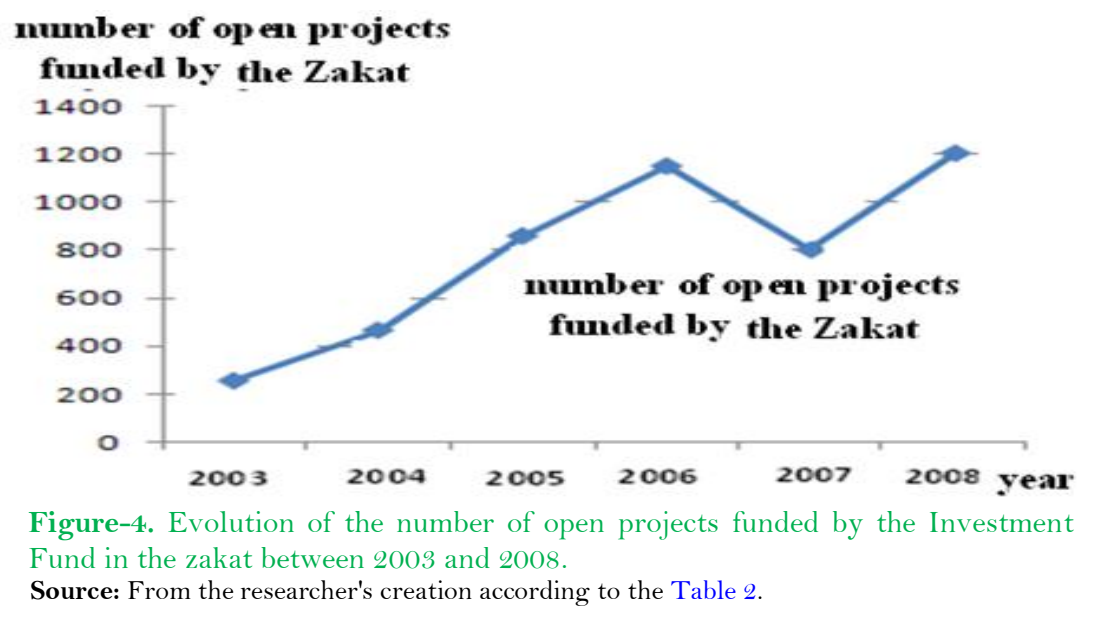

\section{Control Tools of Fund Activities}

Every citizen and each body have the right to consult the total income from the Zakat collection and how it was distributed. Therefore, the administrative apparatus of the Zakat Fund has established a set of different adopted instruments which enable it to control the inflow and out flow activities of funds.

- Detailed reports which are published by all media.

- Setting detailed lists at the disposal of any body or association to consultthe channels of disbursement of Zakat.

- Publication of the figures in detail on the Ministry's website.

- Adopting the Zakat Fund newsletter as an informative tool that is accessible to all parties and individuals.

- The Muzaki sends donation or charity voucher to the administrative body of the fund to control the collection of Zakat, or sending copies to the committees of various deliberations at all levels.

\section{Procedures for Obtaining Financial Support from the Zakat Fund}

The interest-free loan has become one of the channels providing finances for low-income groups which have limited income due to lack of adequate guarantees. Moreover, the importance of the interest-free loan in Islam and its reward set by Allah, has received a great response and this is because it provides its demanders with possible solutions to issues one has in life; but more than that,it is good for him that the great reward and its multiplication by Almighty Allah. Thus, we find no trace or impact of this on the modest Islamic banking culture in Algeria today, although it can be classified as a social responsibility, and it is considered one of the tributaries that Islam has urged to bridge the gap between rich and poor and transfer surplus wealth to Muslims in need and expand them. It also contributes to increased productivity in the society.

To obtain an interest-free loan from the Zakat Investment Fund, the Ministry of Awqaf and Religious Affairs set a series of administrative procedures. The loan applicant must submit a request for benefit to the Zakat Fund's local committee for subsequent check according to the following criteria:

1. Eligibility of the loan applicant, and this is done at the level of Zakat units in mosques in cooperation with the neighbourhood committees.

2. The Zakat Fund's State Committee shall arrange the applications received according to priority in the accrual on the basis of the most affected and the most beneficial (high profitability, greater employment).

3. Preparation of the list of eligible applicants, one specific directed to the National Agency for Youth Support and Employment and another specific one to the National Fund for Unemployment Insurance to invite the beneficiaries in order to call them to prepare the application file in accordance with the procedures in force.

4. Preparation of a single list of eligible beneficiaries with the National Agency for the Support and Employment of Youth and Beneficiaries with the National Unemployment Insurance Fund approved by the State Committee to Al Baraka Bank to determine the final possibility of financing the projects or not according to the criteria that it usually adopted.

5. Prepare a list of beneficiaries under the framework of microfinance and Garmin and direct them to $\mathrm{Al}$ Baraka Bank to call them to form a file to benefit in accordance with the procedures in force.

\section{Procedures for Obtaining the Loan with Al Baraka Bank}

The application of Al-Qard Al-Hasan has expanded to the level of the Islamic bank "Al-Baraka" and has highlighted the real role of the Islamic bank as a charity, even if the The social aspect takes on a great dimension in its function. Helping to minimize the risks to which Zakat Fund and Al Baraka Islamic Bank could be exposed.

The initiative to create the Zakat Fund was taken by the Ministry of Religious Affairs and Endowments to start working with good credit to help young people who wish to create their small or micro enterprise to contribute to the establishment of rules integration into the world of business and employment, including job creation, to reduce unemployment and fight poverty. You will find below how to obtain the loan and the procedures to follow to obtain it. The application of Al-Qard Al-Hasan has expanded to the level of the Islamic bank "Al-Baraka" and has highlighted the real role of the Islamic bank as a charity, even if the The social aspect takes on a great dimension in its function. Helping to minimize the risks to which Zakat Fund and Al Baraka Islamic Bank could be exposed.

The initiative to create the Zakat Fund was taken by the Ministry of Religious Affairs and Endowments to start working with good credit to help young people who wish to create their small or micro enterprise to contribute to the establishment of rules integration into the world of business and employment, including job creation, to reduce unemployment and fight poverty. You will find below how to obtain the loan and the procedures to follow to obtain it. 


\subsection{Procedures for Funding the Youth Employment Project}

For this type of loan, young people can ask for financing from Al Baraka Bank, following the following steps:Al Baraka Bank shall provide a certificate to the young individual proving that it has a balance of its personal contribution in whole or in part and the required insurance premium, the costs of studying the file as the case may be, or the amount required in case of mixed financing (between him and the Agency) on the basis of interest-free loan contract.

- The young individual shall complete the procedures for obtaining the qualification certificate of the National Agency for Youth Support and Employment in his city.

- The young individual shall go to Al Baraka Bank to complete the procedures for obtaining the supplementary loan required according to the case, and this after obtaining the qualification certificate from the National Agency for Youth Support and Employment.

\subsection{Procedures for Applying for Funding with the National Unemployment Insurance Fund}

This type of loan belongs to a certain group of people in the community and is carried out according to the following procedures:

- Al Baraka Bank for Youth shall provide a certificate proving that it has a balance in the amount of its personal contribution in whole or in part and the required insurance premium, the costs of studying the file as the case may be, or an obligation to pay the conditional entitlements from the National Unemployment Insurance Fund.

- The young person shall complete the procedures for obtaining the qualification certificate with the National Unemployment Insurance Fund in his / her country.

- The young person shall submit to Al Baraka Bank to complete the procedures for obtaining the supplementary loan required by the case, after obtaining the qualification certificate from the National Unemployment Insurance Fund.

- Note: For cases A, B, and in exceptional cases, the beneficiary may be entitled to supplementary subsidy from the Zakat Fund, in addition to the funds above, on a basis of Musharaka, Mudarabah, Murabaha (genres of commercial activities)if the Bank is unable to provide full supplementary funding.

\subsection{Microcredit Financing Procedures}

This type of loan is characterized by the fact that the amount of the borrower is very small compared to the aforementioned loans. The method of obtaining is according to the following steps: The beneficiary in this category is called to Al Baraka Bank to prepare a file in accordance with the procedures followed:

- The beneficiary signs the interest-free loan contract.

- The bank shall pay the supplier directly without giving the money in cash to the beneficiary.

- The Bank may provide supplementary financing if the micro-project requires it in accordance with the procedures usually adopted.

It should be noted that the beneficiaries of this funding may not be in the two previous categories, where it may include women staying at home and are able to be involved in certain activities, and may include as well the category of disabled people who are able to work. However, the projects funded in this framework do not exceed Higher funding determined by the National Zakat Fund Committee.

\section{Other Projects, their Support and Protection}

There are other projects different from those mentioned above, which are:

\section{i. Mutual Projects}

These projects consist of partnership between Al Baraka Bank and Zakat Investment Fund, based on studies conducted by the Bank to determine the size and quality of projects to be established in each state, which are usually intended to employ Zakat beneficiaries who are able to work.

These projects shall be subject to separate agreements between the Bank and the Ministry whenever necessary, and shall develop as the Fund proceeds.

\section{ii. Support for Projects Secured by the SME Loan Guarantee Fund}

It is construed through finding means to support these projects, which are guaranteed by this fund, through subsequent procedures that may be interpreted in the form of an agreement between the Ministry and this Fund, but currently the cases are handled according to their status and in cooperation with Al Baraka Bank, which is considered a member of this Guarantee Loan Fund for Small and Medium Enterprises (Masdour, 2009).

\section{Risks and Guarantees}

Free-interest loan represents a risk that has no guaranteed consequences either in terms of the use of funds without an appropriate outcome or jeopardizing the bank's credibility to the risk of non-payment of some loans as the beneficiaries believe that it is zakat and therefore right, they do not have to return it. To mitigate the risk, we suggest the following:

1. The loan is limited under market securities.

2. The lending policy should be carefully and clearly designed to promote any personal interests or mediation and to adopt this policy on clear and explicit criteria and priorities.

3. The loan should be proceeded with an adequate guarantee that provides a limited ceiling for the size and duration of each type of loan so that the lending activity remains within the limits of generally short-term loan and in amounts that meet the purpose of lending without expansion. 
Meanwhile, the guarantee that can be used in securing the recovery of loan funds, it is suggested in particular, that the Funds secured by a government agency, whether by litigation or legal proceedings, and that they are treated as state funds which possess quick collection and confinement, as well as taking credible guarantees from borrowers themselves :

i. Mortgaging the equipment, to cover one of the remaining instalments on the borrower, thereby minimizing the loss to which the Fund may be exposed.

ii. Guarantees: The guarantor is one of the parties that is keen on the success of the project, especially if it has a place in the market, training and qualification; training, training and qualification are essential in the virtuous management of micro projects, which cannot be dispensed with.

iii. Joint collective insurance; joint insurance with the Fund's management against various risks is an effective tool for protecting investment fund loans.

iv. There is also the Garmin Guarantee Fund; the Zakat incubators, etc.

\section{Conclusion and Recommendations}

Zakat is a religious pillar and a financial resource that is very important in exploiting its resources and investing them socially and economically. Therefore, reminding the believers of this particular pillar and urging the rich and affluent of them at every opportunity to pay and collect them through the media and all other available means will be very important. And on the other hand, to enhance the trust of the public and the benefactors in the neighbourhood committees and charities in order to achieve the purposes of Islamic law as well as enhance the financial development role of charities.

Zakat funds will thus double, with opportunities for recreation for the poor families and thosein need. The Zakat Fund will also be a source of interest-free loans and support for youth and unemployed to achieve their programs.

These loans, which are considered from a moral and ethical types of loans, which are a form of cooperation and sympathy originated from human instinct. It is from the material or economical perspective expected to have a tangible role in a society that attempts to apply the Islamic economy despite the dominance of the physical pattern in life and the idea of Riba on financial transactions.

In the Islamic economy, one of the main objectives of monetary policy will be to maintain the purchasing power of money. The expansion of interest-free loans will contribute to achieving this goal because the investor will be able to postpone the use of its money in the future without fear of its low value. An interest-free loan -with the stability of the purchasing power of money - can additionally be the preferred means of saving for a saver who does not wish to bear the risk of investing. As with tight investment opportunities, El Hassan (interest-free) loan is a key area for channelling savings involved in correcting the recession and creating more effective demand.

In the Islamic economy, one of the main objectives of monetary policy will be to maintain the purchasing power of money. The expansion of good loans will contribute to achieving this goal therefore (Masdour, 2009):

1. Encouraging the people who pay Zakat (investors) to deal with Islamic banks.

2. Encouraging investors in Islamic banking in Algeria.

3. Expanding the applications of the interest- free (El Hassan) loan at the level of Islamic banks and highlight the real function of the Islamic Bank that it is not a charity, even if the social aspect has a broader perspective in its application.

4. Reducing the risk that the Islamic Bank might come through.

\section{References}

Masdour, F., 2009. Al-Qard Al-Hassan risk from the zakat fund and ways of covering it; Dar Houma.

Ministry of Religious Affairs and Endowments, 2004. Cooperation agreement in the field of investment of zakat funds between Al Baraka Bank of Algeria and Ministry of Religious Affairs and Endowments.

Mohammed, A.H. and F. Mohammed, 2006. Suggestions on the loan Hassan Available from http://www.kamalhattab.info.

Publications of the Ministry, 2009. Publications of the ministry of zakaf and religious affairs. Algeria: Zakat Fund. 